\title{
ELEMENTY PAMIĘCI SPOŁECZNEJ W KONSTRUOWANIU LOKALNEJ MARKI. LOKALNA PRZESZŁOŚĆ WIELOKULTUROWA JAKO (NIE)PRODUKT TURYSTYCZNY - STRATEGIE STOSOWANE W PRZEMYŚLU I SANOKU
}

\section{Marka a pamięć społeczna - wymiar lokalny}

Marketing terytorialny pojawił się w Polsce właściwie dopiero po 1989 roku, kiedy upodmiotowione samorządy uzyskały realne narzędzia kreowania lokalnej polityki (przede wszystkim w ramach wciąż dyskusyjnej ustawy z dnia 8 marca 1990 roku o samorządzie gminnym). Sama cezura czasowa wydaje się być w pełni zrozumiała - przestawienie gospodarki państwa na tory rynkowych relacji wywołało także konkurencję pomiędzy jednostkami terytorialnymi, a centralne zarządzanie zostało zastąpione przez niczym nieskrępowaną grę rynkową, w której w szranki stanęły podmioty posiadające różne zasoby i możliwości. Co więcej, zjawisko kreowania wizerunku miasta, gminy czy nawet regionu staje się coraz powszechniejsze, bowiem traktowane jest jako instrument pozyskiwania nowych inwestorów [Perzyńska 2013: 121], a tym samym kreowania rozwoju zbiorowości lokalnej.

Proces komercjalizacji wizerunku miasta, gminy czy regionu uległ wzmocnieniu $\mathrm{w}$ związku $\mathrm{z}$ rozwijającym się przemysłem turystycznym. Wzrost znaczenia przede wszystkim turystyki miejskiej [Żabińska 2012; 2013; MSiT 2014; GUS 2016] przełożył się na zmianę w zarządzaniu miastem - z miejsca, w którym się mieszka i pracuje, miasto przekształciło się w atrakcję turystyczną przynoszącą wymierne korzyści [Michałowski 2003: 93]. W ferworze szukania lokalnej specyfiki i kolejnych prób podkreślania własnej wyjątkowości na potrzeby pozytywnego odróżnienia się z własną ofertą od innych podobnych na rynku, zaczęto szybko sięgać po szeroko rozumianą przeszłość [Kwiatkowski 2009: 131-132]. Nagle okazało 
się, że odpowiednio prezentowana przeszłość miasta może stać się towarem, który zainteresuje turystów, a jednocześnie będzie stanowić legitymizację dla kreowanej indywidualności czy wyjątkowości miasta w postaci marki. To wymagało jednak redefinicji posiadanych już zasobów historycznych, a także sięgnięcia po wcześniej niewykorzystywane $\mathrm{z}$ różnych względów elementy przeszłości.

Budowane w miastach w okresie rozwoju przemysłowego sale koncertowe, galerie sztuki, muzea i biblioteki służyły - w pierwotnym założeniu - gromadzeniu i przechowywaniu dziedzictwa kulturowego, i w tym sensie były zjawiskiem typowym dla wielu miast, które odniosły sukces w rozwoju społeczno-gospodarczym [Michałowski 2003: 93]. Przechowywane dziedzictwo kulturowe miało w pierwszej kolejności stanowić dowód na rolę i znaczenie danej zbiorowości miejskiej w szerszym układzie kulturowym, miało być powodem do dumy danej zbiorowości miejskiej [Michałowski 2003: 93] i miało konstytuować poczucie bycia częścią większej całości kulturowej. W tym znaczeniu historyczny obiektywizm i naukowa rzetelność gromadzonych zbiorów były istotne. Cechy te tracą jednak na znaczeniu, jeżeli głównym celem jest przyciągnięcie uwagi zewnętrznego odbiorcy - z perspektywy przyjętej w prezentowanych analizach to szczególnie pamięć społeczna stała się rezerwuarem potencjalnych odwołań do przeszłości, dostarczając turystom oryginalnych przeżyć, ponieważ najpełniej wpisuje się w wymiar lokalny danego miasta. Dzisiaj te same sale koncertowe, galerie sztuki, muzea czy biblioteki eksponują swoje zasoby w celach komercyjnych, co oznacza konieczność sięgania po lokalne elementy specyficzne, a więc po lokalne przypisy do treści już zgromadzonej, aby zainteresować tą konkretną ofertą potencjalnych turystów.

W praktyce oznacza to próbę wzbogacenia rzetelności naukowej „martwych” zasobów historycznych oryginalnością „żywej” pamięci społecznej. Najprościej rzecz ujmując, pamięć społeczna, w przeciwieństwie do historii, jest zbiorem wyobrażeń członków zbiorowości o przeszłości [Szacka 2006: 19]. W tym znaczeniu pamięć społeczna nie jest zbiorem potwierdzalnych naukowo faktów składających się na wiedzę o przeszłości, których jakość może być weryfikowana w toku rzetelnej dyskusji. Pamięć społeczna jest społecznie wytwarzana, przekształcana i zbiorowo negocjowana w zakresie odpowiadającym bieżącym interesom zbiorowości [Golka 2009: 15] - jest płynna, zmienna w czasie, silnie nacechowana emocjonalnie i wybiórcza. Co więcej, dla aktualnej, bieżącej tożsamości zbiorowej równie ważne jak pamiętanie, jest także zapominanie konkretnych elementów przeszłości. 
Pamięć społeczna jest więc kwintesencją „kultury wysokiego kontekstu" [Hall 2001], co jest konstatacją istotną z punktu widzenia ram teoretycznych analiz prowadzonych w tym tekście. Oznacza to w praktyce, że jest to fragment kultury w pełni zrozumiały wyłącznie dla członków danej zbiorowości, a w przypadku społeczności lokalnej - w wymiarze lokalnym. Albo rzecz ujmując nieco inaczej, dana jednostka jest o tyle członkiem społeczności lokalnej, o ile rozumie wszystkie znaczenia wynikające z lokalnej pamięci społecznej [Jałowiecki, Szczepański, Gorzelak 2007]. Jednocześnie marka produktu, marka terytorialna rozumiana jako nośnik informacji na temat produktu, w tym produktu turystycznego, jest z całą pewnością zjawiskiem z obszaru „kultury niskiego kontekstu” [Hall 2001] - z definicji powinna być jednoznacznie rozumiana przez dowolnego odbiorcę.

Marka jest komunikatem dla konsumenta, który posiada niepełną wiedzę na temat produktu, jego jakości i alternatywnych cech (Perzyńska 2013, s. 120). W przypadku produktu tak złożonego, jakim jest miasto, marka jest połączeniem korzyści funkcjonalnych produktu $\mathrm{z}$ wartością dodaną i to właśnie ta wartość dodana, rozumiana jako pozytywne wyobrażenie na temat produktu, jest elementem przewagi konkurencyjnej - w tym przypadku jednostki terytorialnej [Raszkowski 2013: 81]. W tak rozumianej marce brak więc miejsca na niuanse, wieloznaczność i wagę różnorakich kontekstów, wręcz przeciwnie - komunikat winien być zwarty, jednoznaczny, nastawiony na jasno sprecyzowany cel.

Co więcej, wśród głównych adresatów marketingu terytorialnego można wskazać inwestorów, turystów, ale także mieszkańców miasta [Michałowski 2003: 92]. Dla pierwszych kluczową informacją jest ta dotycząca korzystnych warunków inwestycyjnych, dla turystów komunikat skupia się na szczególnych walorach turystycznych danego miasta, a w przypadku mieszkańców jest elementem budowania tożsamości lokalnej [Kempny 2004; 2005]. Uogólniając, można więc stwierdzić, że marka miasta jest formą komunikacji zarówno na potrzeby zewnętrzne, jak i wewnętrzne.

Za wykorzystanie elementów lokalnej pamięci społecznej w ramach miejskiej marki, a więc za przeniesienie znaczeń „kultury wysokiego kontekstu” do komunikatu na poziomie „kultury niskiego kontekstu”, odpowiedzialni są animatorzy marki. Wydaje się, że w relacji do zewnętrznego odbiorcy komunikatu zawartego w marce miejskiej lokalni animatorzy marki są raczej „tłumaczami”, ponieważ ich rola polega na wykorzystaniu oryginalnych elementów przeszłości w kreowaniu indywidualności społeczności lokalnej, na ukazaniu i wytłumaczeniu specyfiki miasta. Innymi słowy tłumaczą oni wieloznaczności zrozumiałe dla członków 
społeczności lokalnej, a zupełnie nieczytelne dla przybysza z zewnątrz. $\mathrm{Z}$ kolei w relacji do wewnętrznego odbiorcy ci sami animatorzy marki stają się bardziej „prawodawcami”, ponieważ ich rola polega na arbitralnym wyborze konkretnych elementów przeszłości i wskazaniu ich jako kluczowych dla lokalnej tożsamości. W praktyce jest to wskazanie, co z punktu widzenia bieżących interesów społeczności warte jest zapamiętania i eksponowania, także na zewnątrz, a co z kolei ukrycia i ostatecznego zapomnienia, także przez członków społeczności lokalnej ${ }^{1}$.

Rozważania te stanowiły punkt wyjścia dla pomysłu na analizę wtórną wywiadów pogłębionych, które zostały zrealizowane w 2013 i 2014 roku $\mathrm{z}$ animatorami marki miejskiej (osobami odpowiedzialnymi za organizowanie lokalnych świąt miejskich i reprezentującymi miejskie instytucje kultury). Przemyśl i Sanok to miasta o różnych losach historycznych, więc podejmując próbę porównania strategii wykorzystania pamięci społecznej w konstruowaniu lokalnej marki należało poszukać w pierwszej kolejności elementu wspólnego, który stanowiłby punkt referencyjny w interpretacji argumentów używanych przez respondentów. Za taki wspólny mianownik uznano wielokulturową przeszłość obu miast, które do II wojny światowej były zamieszkiwane przez liczne społeczności m.in. ukraińskiego i żydowskiego pochodzenia.

Według Spisu Powszechnego z 9.12.1931 roku dla województwa lwowskiego [GUS 1938: 39-40], w Przemyślu (liczącym wówczas 51038 mieszkańców) mieszkało 25154 rzymskich katolików, 8278 osób wyznania grekokatolickiego i 17326 żydów. Sanok, jako miasto znacznie mniejsze, ujęty był zbiorczo w statystykach dla całego powiatu, dla którego jednak proporcje mieszkańców miast były bardzo zbliżone do przemyskich - ok. 50\% rzymskich katolików, 34\% żydów, oraz 15\% grekokatolików. Ta historia zakończyła się pod koniec lat 40. XX wieku, kiedy to eksterminacja Żydów oraz masowe przesiedlenia doprowadziły do homogenizacji etnicznej ludności. Według Spisu Powszechnego z 20.05.2002 roku [GUS 2002] w Przemyślu mieszkało 814 Ukraińców (1,2\% populacji miasta), a w Sanoku 79 Ukraińców (0,2\% populacji).

W tekście przyjęto rozumienie wielokulturowości jako opis stanu lub kontekstu, nie jako polityki wobec mniejszości etnicznych czy wręcz ideologii dotyczącej relacji między różnymi kulturami. W przyjętym rozumieniu tego pojęcia Polska jest krajem „tuż po” i „tuż przed” wielokulturowością - mając za

1 Koncepcja reprezentacji społecznej i roli elit lokalnych w rozumieniu przyjętym w tekście jest szczegółowo omówiona w: [Kurczewska 2009]. 
sobą historię kulturowego zróżnicowania oraz wyzwania związane ze współczesnymi migracjami przed sobą [Kempny, Kapciak, Łodziński 1997].

Ostatecznie więc cel artykułu został zdefiniowany jako próba odtworzenia strategii wykorzystania lub rezygnacji z lokalnych zasobów pamięci społecznej wielokulturowości w procesie konstruowania marki miejskiej. Ponieważ w pierwotnej wersji scenariusze wywiadów dotyczyły miejskich świąt, postawione zostało pytanie, czy przy opisie tych świąt wątki wielokulturowej lokalności w ogóle się pojawiają i w jaki sposób jest to wyjaśniane przez lokalnych animatorów marki.

\section{Metodologia}

Na potrzeby niniejszego tekstu poddano analizie w sumie 18 ustrukturyzowanych wywiadów pogłębionych, które zostały zrealizowane w Przemyślu (8 wywiadów na przełomie sierpnia i września 2013 roku) oraz w Sanoku (10 wywiadów w sierpniu 2014 roku) z przedstawicielami szeroko rozumianych animatorów lokalnej marki reprezentującymi samorządowe i stowarzyszeniowe instytucje kultury. Były to osoby zaangażowane w lokalną działalność kulturalną, a częściowo także w organizację wydarzeń, które stanowiły główny przedmiot badania: przemyską Wincentiadę i Jarmark Sanocki.

Opisywana w tekście analiza miała charakter wtórny względem pierwotnych założeń scenariusza wywiadu. Ten został podzielony na następujące sekcje, które strukturyzowały rozmowę z respondentami: (a) święto lokalne (ogólny portret święta, historia święta, organizacja obchodów tegorocznego święta, rola poszczególnych lokalnych aktorów społecznych, rola rozmówcy w organizacji święta, znaczenie święta dla społeczności lokalnej), (b) marka lokalna, produkt lokalny (znaczenie święta, specyfika święta na tle podobnych w Polsce, święto jako marka lokalna, ważne lokalne postaci, wydarzenia, symbole i miejsca dla lokalnej marki, co decyduje o lokalnej marce, jak i z kim respondent promował(a)by lokalną markę).

Podjęto próbę poszukiwania elementów lokalnej pamięci społecznej $\mathrm{w}$ wypowiedziach badanych przedstawicieli lokalnych animatorów marki w celu wskazania jej znaczenia dla kształtowania lokalnej marki. Analizę wywiadów podzielono w sumie na cztery etapy. W pierwszym, po wstępnej selekcji materiału empirycznego, miała miejsce lektura transkrypcji przeprowadzonych rozmów (odrzucono dwa wywiady z 2014 roku przypisane do Jarmarku Sanockiego, które zostały zrealizowane z reprezentantami Jasła i Krosna - były one ważne dla pierwotnego celu badania, ale nieistotne ze 
względu na postawiony cel w tym artykule). Następnie, w drugim kroku miało miejsce kodowanie treści przy wykorzystaniu oprogramowania Atlas.ti - kody kreowane były na podstawie lektury, ale w odniesieniu do założonego celu analizy, stąd dążono do wychwycenia możliwie wszystkich wątków wpisujących się w kontekst pamięci społecznej i marki lokalnej, a jednocześnie zmierzano do nasycenia i zamknięcia listy kodów. W trzecim etapie dokonano kwerendy cytatów według przypisanych kodów, a więc w praktyce dokonano wyabstrahowania konkretnych wątków z całości wywiadów celem dokładniejszej ich analizy. Wreszcie, na podstawie analizy kwerendy kodów i przypisanych do nich cytatów podjęto próbę skonstruowania modeli odwzorowujących typową dla danej lokacji linię argumentacyjną w kontekście relacji między lokalną pamięcią społeczną a lokalną marką.

Finalnie, na podstawie wypowiedzi respondentów dotyczących pamięci społecznej i lokalnej marki, wypracowano 16 kodów (prezentowanych tutaj w kolejności alfabetycznej wraz z liczbą przypisanych do nich cytatów w pełnej puli wziętych do analizy wywiadów): "animatorzy lokalnej tradycji” (19), „konflikty na tle kulturowym” (11), „konflikty na tle organizacyjnym” (10), „lokalna tradycja” (15), „lokalna tradycja - adresaci” (28), „lokalna tradycja - mieszczaństwo” (3), „lokalna tradycja - nieważna wielokulturowość” (9), „lokalna tradycja - ważne dla tożsamości” (17), „lokalna tradycja - wielokulturowość” (29), „lokalna tradycja a marka” (18), „lokalna tradycja a marka - różnica” (7), „lokalna tradycja a ponadregionalizm” (2), „lokalna tradycja a rozpoznawana historia” (9), „lokalna tradycja a znana historia” (1), „nowa lokalna tradycja - literatura” (2), „wyobrażenie marki” (35)

\section{Sanockie reaktywowanie wielokulturowości jako lokalnej marki}

Na pytanie o najbardziej charakterystyczne dla miasta postaci, wydarzenia historyczne czy symbole, a więc na pytanie o „wyobrażenie marki lokalnej”, respondenci w Sanoku najchętniej wskazywali na Muzeum Budownictwa Ludowego i Park Etnograficzny w Sanoku, Muzeum Historyczne w Sanoku - a dokładnie rzecz biorąc mieszczące się w nim Galerię Zdzisława Beksińskiego oraz wystawę stałą Sztuka Cerkiewna XII-XX wieku. Wspominano także o sukcesach sportowych sanockiej drużyny hokejowej oraz podupadających tradycjach sanockiej fabryki Autosan. Co ciekawe, dla niektórych rozmówców właśnie Muzeum Budownictwa Ludowego i Park

2 Baza transkrypcji wraz z kodami jest dostępna u autora tekstu w formacie .hpr6. 
Etnograficzny w Sanoku oraz wystawa Sztuka Cerkiewna XII-XX wieku były jednocześnie dowodem na wielokulturowość miasta i jego najbliższego sąsiedztwa. W tym kontekście będący przedmiotem badania Jarmark Sanocki wpisywał się w spójną koncepcję lokalnej marki, będąc przecież kontynuacją Jarmarku Ikon. Najpełniej to „wyobrażenie lokalnej marki” i relacji z lokalnym świętem odzwierciedla wypowiedź jednej z respondentek:

Jarmark jest związany z Sanokiem, ale gdybym chciała przypisać jakieś symbole, to tak to widzę: Sanok skansen, Sanok Beksiński, Sanok - Jarmark. Tu trzeba pamiętać o ikonach, bo Jarmark jest spadkobiercą Jarmarku Ikon. Podsumowując: sam Jarmark nie buduje marki miasta, jest częścią innych działań, które budują markę. Markę Sanoka budują: Autosan, ikony, Beksiński, skansen, Bieszczady. Jarmark jako dopełnienie tego wszystkiego jest wydarzeniem, które to wszystko integruje, (SKS4, kod: „wyobrażenie lokalnej marki”).

Punktem wyjścia jest więc świadomość atutów miasta nawiązujących także do wielokulturowości i próba obudowania tego wydarzeniami towarzyszącymi. Tak to właściwie prezentują osoby odpowiedzialne za organizowanie wydarzenia:

Wiele lat temu zaistniała tutaj impreza Jarmark Ikon i bieszczadzki Szlak Ikon. Do niego nawiązywaliśmy - ziemia sanocka jest znana z ikon, tak poprzez historię - byli tu kiedyś prawosławni, nadal są, ale nie w takiej liczbie, i jest największe muzeum ikon w Europie. Jarmark miał być dopełnieniem zorganizowanego przez nas Szlaku Ikon. Ten jarmark i szlak cieszył się dużą popularnością wśród turystów, nawet wśród turystów z Francji, widnieje on w znanym francuskojęzycznym przewodniku, (SKS2, kod: „lokalna tradycja a marka”).

Dla lokalnej marki jedną z centralnych kategorii są więc ikony, co wymusza odwołanie do wielokulturowości, ponieważ nie są wytworem abstrakcyjnym, ale są zasobem miasta dzięki temu, że w przeszłości teren ten był zamieszkiwany przez ludność ukraińską wyznania prawosławnego i grekokatolickiego. Wielokulturowość jest więc elementem „lokalnej tradycji", ale w sposób zdecydowanie uogólniony, niejako konieczny z powodu niezaprzeczalnych faktów. W odwołaniach do przeszłości respondenci z Sanoka znacznie konkretniej wskazują na inne elementy historii:

Jakiś Jacek Dydyński, szlachcic opisywany przez Komudę, zagończyk - jego młodzież kojarzy, bo czyta książki Komudy, więc on może być kojarzony z Sanokiem. Też Szwejk, Artur Andrus i inni współcześnie. Sawicka z Polsatu. Andrus dawał tu u nas koncert charytatywny dla uczniów, (SKS3, kod: „lokalna tradycja a rozpoznawana historia"). 
Natomiast mówiąc o dawnych mieszkańcach miasta, pojawiają się ogólniki, jak w poniższej wypowiedzi:

Ale pamięta się o przeszłości, zostały pieśni, jakieś stroje, wyroby. Zwłaszcza ukraińska kultura jest tu widoczna choćby przez ikon, (SKS4, kod: „lokalna tradycja a rozpoznawana historia").

Szczególnie widoczne jest to w przykładzie przytoczonym przez przedstawicieli mniejszości ukraińskiej w Sanoku, którzy przywoływali ważne dla swojej społeczności wydarzenie, jakim było odsłonięcie tablicy pamiątkowej w Gimnazjum nr 2, poświęconej trzem wybitnym pisarzom (polskiego, żydowskiego i ukraińskiego pochodzenia), w tym Bohdanowi Ihorowi Antonyczowi:

Sanok powinien szczycić się tym, ale było to odrzucane, odrzucane (...). Nie zostaliśmy zaproszeni przez władze miasta na tę akcję, nas zaprosiła szkoła, żebyśmy my jako Ukraińcy przyszli na otwarcie, zaśpiewali hymn Ukrainy. Myśmy przyszli. Okazało się, że trzeba tam zaśpiewać i hymn polski, bo nie było komu, więc zaśpiewaliśmy i hymn ukraiński i polski, (SKA5, kod: „lokalna tradycja - wielokulturowość").

Jeśli więc w wypowiedziach respondentów poszukiwać śladów lokalnej pamięci społecznej, to przetrwało wspomnienie, że Sanok był zamieszkiwany przez ludność ukraińskiego pochodzenia, ale ludności tej już właściwie nie ma albo pozostali nieliczni. Należy dodać, że w wypowiedzi Polaka (przedstawiciela instytucji samorządowej) na temat tego samego wydarzenia pojawiają się pisarz ukraiński i polski, ale nie ma już żydowskiego. Po Ukraińcach pozostały jedynie ikony, które wzbudzają duże zainteresowanie turystów, zwłaszcza zagranicznych. Dzięki tym ikonom można więc promować miasto i budować jego markę, dlatego też pojawił się pomysł na Jarmark Sanocki, jako wydarzenie przeznaczone głównie dla turystów właśnie.

Jeżeli wziąć pod uwagę, że był jeden stragan z Ukrainy, nasi Ukraińcy, znaczy Polacy ukraińskiego pochodzenia, czy Ukraińcy polskiego pochodzenia, przychodzą, zobaczą, jakoś wielkiej konsumpcji tam nie ma, swoich straganów my też nie mamy; wielokulturowości ... zobaczyłam właśnie, że Polacy robią naszą kulturę - te same ikony, przecież to jest tradycja ukraińska, (SKA5, kod: „lokalna tradycja - wielokulturowość").

W przytoczonej wypowiedzi uwidacznia się właściwie kwintesencja charakteru Jarmarku Sanockiego, którego istota sprowadza się do kon- 
sumpcji tradycji ukraińskiej robionej przez Polaków w Sanoku, ponieważ właśnie w tym mieście znajduje się największe w Europie muzeum ikon, a w bezpośrednim sąsiedztwie znajdują się Bieszczady, chętnie odwiedzane przez zagranicznych turystów.

Pozostaje oczywiście jeszcze pytanie o instytucje czy osoby odpowiedzialne za animowanie całego przedsięwzięcia związanego z lokalną marką. W przypadku Jarmarku Sanockiego, ale także w przypadku właściwie wszystkich wydarzeń kulturalnych na terenie miasta, w pierwszej kolejności, jeśli nie jako jedyny podmiot, wskazywany jest samorząd lokalny i podlegające mu instytucje.

Podglądaliśmy, jak to robią w Lublinie - tam samorząd koordynuje działania, gdzie są imprezy dzielnic miasta, każda chce się jakoś pokazać. Myśmy także to próbowali robić, ale nie było zainteresowania. Ważny jest mecenat, a mecenasa interesuje szeroki odbiór. (...) Samorząd raczej, bo poszczególne instytucje kultury należą do różnych gestorów (...) każde jest przynależne do innej władzy. I trudno o koordynację, (SKS3, kod: „animatorzy lokalnej tradycji”).

Biorąc pod uwagę wymieniane przez badanych charakterystyczne dla Sanoka elementy marki lokalnej trudno nie zauważyć, że faktycznie pozostają one $\mathrm{w}$ gestii podmiotów $\mathrm{z}$ różnych szczebli zarządzania. $\mathrm{W}$ takiej sytuacji rola samorządu miejskiego polega przede wszystkim na koordynowaniu różnorakich działań realizowanych w ramach zadań przypisanych tym instytucjom. Korzystając $\mathrm{z}$ faktu, że Muzeum Historyczne znajduje się na terenie miasta, a w bezpośrednim sąsiedztwie zlokalizowane są Muzeum Budownictwa Ludowego i Park Etnograficzny, przedstawiciele samorządu lokalnego postanowili zaproponować wydarzenie kulturalne, które może czerpać z tych atutów, przyciągając jednocześnie turystów do miasta i budując lokalną markę. W żadnej wypowiedzi na temat animatorów Jarmarku Sanockiego nie pojawił się natomiast podmiot reprezentujący żyjących w Sanoku i powiecie sanockim Ukraińców, nawet w wypowiedziach przedstawicieli środowiska mniejszości ukraińskiej.

Z perspektywy zewnętrznego obserwatora, na podstawie transkrypcji wywiadów przeprowadzonych $\mathrm{z}$ osobami odpowiedzialnymi za kulturę w Sanoku, można więc podjąć próbę rekonstrukcji strategii argumentacyjnej dotyczącej Jarmarku Sanockiego w kontekście lokalnej pamięci społecznej wielokulturowości miasta. Cały złożony kontekst lokalnej przeszłości współżycia różnych zbiorowości etnicznych na terenie Sanoka sprowadzony zostaje do dwóch rozpoznawalnych instytucji, które z racji właśnie tej przeszłości są zlokalizowane w Sanoku - do Parku Etnograficznego i Muzeum 
Historycznego, których elementem wspólnym jest prezentowanie ( $w$ formie muzealnych eksponatów) wytworów kultury dawnych („jakichs'”) mieszkańców tych terenów. Do najbardziej rozpoznawalnego wytworu należą ikony, które dzięki wspomnianym instytucjom i dodatkowym inicjatywom, takim jak Szlak Ikon, w sposób naturalny stały się częścią wyobrażenia o lokalnej marce Sanoka. Przez to wielokulturowa przeszłość jest właściwie własnością tego wyobrażenia o marce. Ikony same w sobie stanowią „rękodzieło", które interesuje przede wszystkim zewnętrznego odbiorcę - turystę, a dokładniej rzecz biorąc, zagranicznego turystę (patrz diagram 1).

Jest to więc sytuacja, kiedy społeczność lokalna dysponuje wyrazistym „produktem”, specyficznym dla niej w tym sensie, że silnie powiązanym $\mathrm{z}$ terytorialną lokalizacją, który w wymiarze historycznym pozostaje $\mathrm{w}$ gestii instytucji samych $\mathrm{w}$ sobie dobrze rozpoznawalnych na zewnątrz, które jednak nie podlegają społeczności lokalnej. Podmiotem reprezentującym społeczność lokalną, mogącym stanowić klamrę dla instytucji i produktu, jest samorząd miejski, który postanowił na potrzeby zewnętrznych odbiorców zorganizować cykliczne święto miejskie poświęcone temu właśnie produktowi. Jednak w związku z brakiem czy fragmentarycznością lokalnej pamięci społecznej na temat wielokulturowości (o czym świadczy brak zaangażowania aktorów nieinstytucjonalnych czy przedstawicieli mniejszości ukraińskiej) tradycje ikonopisarstwa są reaktywowane przez Polaków na potrzeby turystów głównie z Zachodniej Europy. Dlatego właśnie strategia sanockiego samorządu miejskiego może być określona mianem „reaktywowania wielokulturowości jako lokalnej marki”, a lokalni animatorzy marki odpowiedzialni za Jarmark Sanocki są nawet nie tyle „tłumaczami”, co wręcz „archeologami” lokalnej pamięci społecznej wielokulturowości.

\section{Przemyskie zapominanie wielokulturowości jako lokalnej marki}

W Przemyślu respondenci pytani o „wyobrażenie lokalnej marki”, czyli najbardziej charakterystyczne dla swojego miasta postaci, wydarzenia, miejsca czy symbole, wskazywali na Forty Twierdzy Przemyśl i Stowarzyszenie Przyjaciół Dobrego Wojaka Szwejka, Muzeum Dzwonów i Fajek, Aleksandra Fredrę i Towarzystwo Dramatyczne im. A. Fredry - Stały Niezawodny Teatr z siedzibą na Zamku Kazimierzowskim w Przemyślu, czyli Teatr Fredreum. W tym kontekście „wielokulturowość” pojawia się tylko raz, podczas wypowiedzi na temat międzynarodowych kontaktów Stowarzyszenia Przyjaciół Dobrego Wojaka Szwejka (wypowiedź respondenta P3, kod: „wyobrażenie lokalnej marki”). 


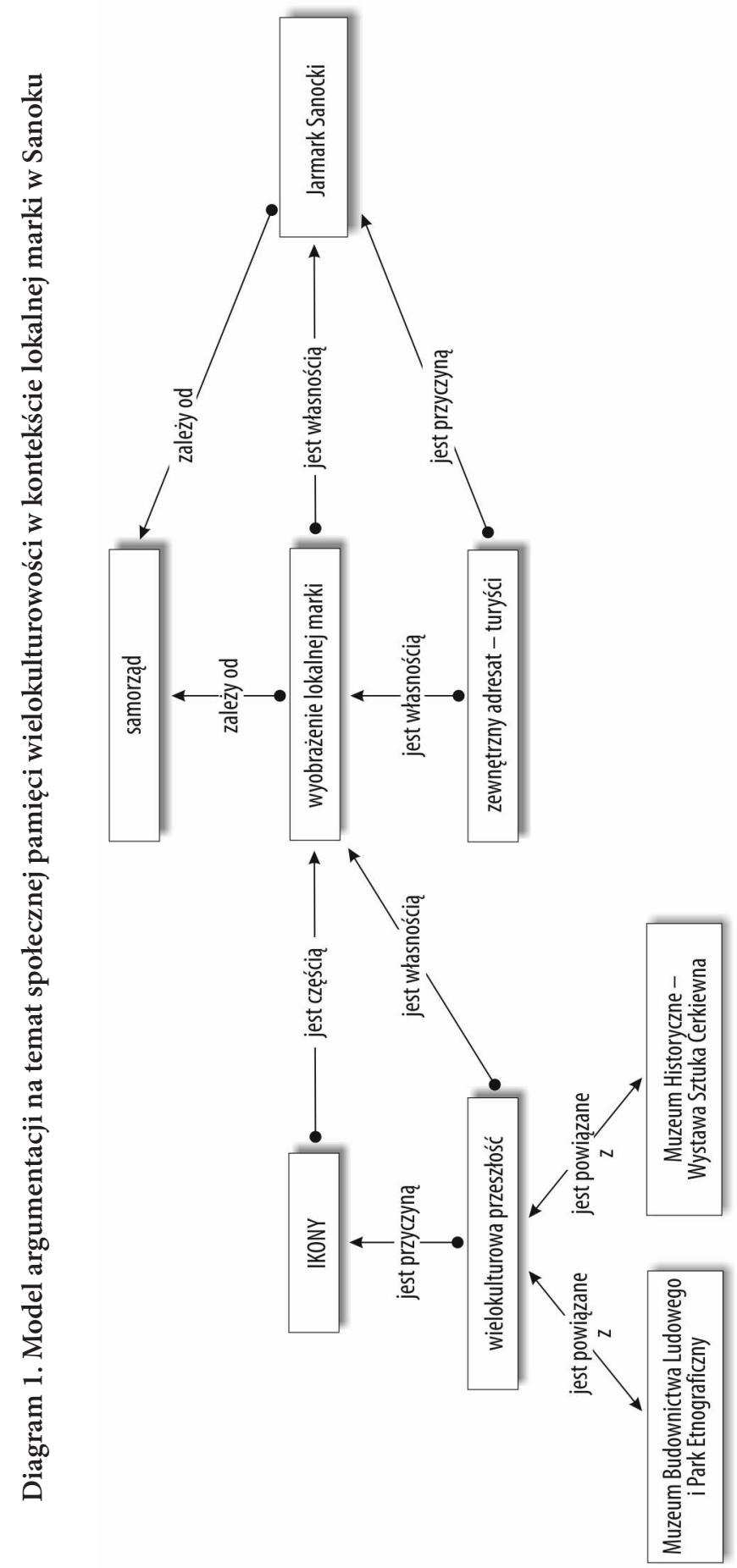


Respondenci skupili się przede wszystkim na znaczeniu miasta jako strategicznej twierdzy w okresie zaboru austro-węgierskiego, pozostałościach po infrastrukturze militarnej i związanej z tym okresem fikcyjnej postaci literackiej stworzonej przez Jarosława Haszka w 1911 roku. Są to zdecydowanie atuty miasta.

Forty. Fortyfikacja. Bezwzględnie. To jest potencjał unikalny. Na przykład fajki dziś produkuje pan X, ale jutro może produkować pan Y; w teatrze jest dziś 30 aktorów, jutro może być 15 innych; święto patrona jest w sierpniu, może być wlutym, załóżmy - już wymyślam, ale Forty są, były i będą. Ich nikt nie przeniesie, one są, one mają historię, mają korzenie. Tylko mogą zmieniać się ludzie, którzy będą tym administrować i one będą zawsze. To jest duży potencjał! To jest bodajże druga co do wielkości fortyfikacja w Europie, o ile mnie pamięć nie myli, (P3, kod: „wyobrażenie lokalnej marki”, „lokalna tradycja a rozpoznawana historia").

Jednak Dni Patrona Miasta Przemyśla Wincentiada nie mają wiele wspólnego z Fortami, fajkami, dzwonami czy Aleksandrem Fredrą. Rozmówcy zdają się być tego świadomi, wskazując, że to konkretne święto skierowane jest raczej do mieszkańców miasta, a nie do przybyszów z zewnątrz.

Patrona miasta, św. Wincentego, podczas którego święta dwu-, trzydniowego odbywają się różnego rodzaju imprezy kulturalno-rozrywkowe, ale też akcje charytatywne, które skierowane są do mieszkańców naszego miasta, mieszkańców Przemyśla i okolic. Natomiast produkt, który może odebrać turysta, to jest przede wszystkim produkt lokalny i produkt kulturalno-rozrywkowy, (P3, kod: „wyobrażenie lokalnej marki”).

Dla badanych Wincentiada to przede wszystkim święto miejskie, reaktywowane w latach 90., ale mające długą i bogatą historię obchodów dni patrona miasta w okresie II Rzeczpospolitej i wcześniej. Obchody Dni Patrona Miasta Przemyśla są istotne dla miejskiej tożsamości mieszkańców Przemyśla, to próba wykazania ciągłości historycznej i oryginalności tej społeczności.

Wincentiada nawiązuje do tradycji lokalnej, jaką był jarmark św. Wincentego w dniu jego święta, po mszy i procesji odbywał się taki jarmark w dawnych czasach. I jest to lokalna tradycja - żeby mieszkańcy miasta mogli tego świętego patrona czcić, (P7, kod: „lokalna tradycja”).

Przy okazji próby odtworzenia historycznych tradycji obchodów lokalnego święta patrona miasta podjęto jednak starania, aby towarzyszące uro- 
czystościom wydarzenia komercyjne w postaci jarmarku nabrały charakteru nieco bardziej turystycznego. Właściwie można stwierdzić, że w opinii respondentów Wincentiada mogłaby pełnić rolę jednego $\mathrm{z}$ elementów lokalnej marki Przemyśla. Punktem odniesienia w tych planach był znany i rozpoznawany w Polsce Jarmark Dominikański w Gdańsku.

Na przykład jest Jarmark Dominikański i każdy go kojarzy, wiadomo, jest to impreza i byłoby fajnie, gdyby za pięć lat, są Dni Patrona Miasta i by było takie podobne skojarzenie. Jeszcze go nie ma, ale to wszystko jest przed nami. Wśród tych dynamicznych wydarzeń i wielu innych rzeczy, które się dzieją, więc może to jeszcze nie jest ten czas na to, żeby to zaistniało jako marka, ale ja myślę, że pewnie to się kiedyś uda, (P1, kod: „lokalna tradycja a marka”).

Punktem wyjścia dla prób przeobrażenia lokalnego święta patrona w markę lokalną skierowaną do zewnętrznego odbiorcy jest fakt, że przedstawiciele Caritas Polska zdecydowali o przyłączeniu się do obchodów Wincentiady $z$ finałem akcji Tornister Pełen Uśmiechów. To zapewniło zainteresowanie ze strony mediów ogólnopolskich i zdecydowanie większe nagłośnienie atrakcji Przemyśla - wspomnianych w pierwszej kolejności elementów marki lokalnej. Niemniej jednak podstawowym celem Obchodów Dni Patrona Miasta Przemyśla jest budowanie tożsamości miejskiej, co zostało wprost wyartykułowane przez jednego z respondentów:

Wincentiada to jest takie budowanie tożsamości miejskiej, Jarmark Turystyczny to jest zwrócenie uwagi na potencjał turystyczny miasta. My mamy jeszcze taką imprezę, która promuje produkt i to produkt w sensie dosłownym - fajka. Przemyśl ciągle produkuje fajki. To jest zagłębie jeżeli chodzi o ten rodzaj rzemiosła, (P1, kod: „lokalna tradycja a marka - różnica”).

Respondenci z Przemyśla w kilkunastu miejscach silnie akcentują rolę Wincentiady w budowaniu poczucia tożsamości miejskiej, nawiązywaniu do przeszłości i tradycji miejskich, poczucia dumy z faktu bycia mieszkańcem Przemyśla. To niezwykle ciekawe zjawisko polegające na budowaniu podwójnego przekazu: jeden skierowany jest do turystów i ma za zadanie eksponować najciekawsze atuty miasta, w przypadku Przemyśla nawiązujące do okresu zaboru austro-węgierskiego; drugi skierowany do mieszkańców, w którym wykazuje się, że Przemyśl „nie kończy się na” Twierdzy Przemyśl.

Najbardziej popularną jest tradycja Austrii, zaborów i Twierdzy Przemyśl. To jest taka najbardziej interesująca w świadomości. Natomiast Wincentiada zwraca uwagę, że hola hola, historia miasta zaczęła się znacznie wcześniej i to trzeba też 
kultywować, i na to trzeba zwracać uwagę, (P1, kod: „lokalna tradycja a rozpoznawana historia").

Jednak najciekawszym aspektem zidentyfikowanych odniesień do przeszłości i ich roli we współczesnych działaniach, a więc lokalnej pamięci społecznej w działaniu, jest to, że właściwie nie pojawia się w nich wątek wielokulturowości. Nie pojawia się spontanicznie - na konkretne pytania w tym kierunku, oczywiście respondenci formułują swoje opinie - pomimo tego, że św. Wincenty z Saragossy jest także świętym Kościoła prawosławnego. Swoją drogą to niezwykle ważne, że na patrona Przemyśla, zamieszkiwanego przez wyznawców kościołów rzymskokatolickiego, grekokatolickiego i prawosławnego wybrany został męczennik rozpoznawany i wspominany we wszystkich tych obrządkach.

Wnioskować można, że Wincentiada jest więc świętem miejskim, poświęconym budowaniu miejskiej tożsamości Przemyśla, ale ze szczególnym akcentem na polskość. Potwierdzenie znaleźć można w wypowiedziach respondentów.

Ja w ogóle mało tutaj widzę, bo z jednej strony taki drażliwy temat, z drugiej strony ... znaczy drażliwy - nie każdy chce się jakby, no krótko mówiąc, w to pchać, bo to wymaga nawiązania kontaktów, pokazywania się z osobami z zagranicy, promowania wręcz takich zespołów, czy jakichś osób. No nie wiem z czym to się wiąże. Znaczy, to się generalnie wiąże $\mathrm{z}$ tym, że są złe relacje między narodami, bo taka jest prawda, nie są dobre, bo jest wzajemne ciągle jakieś tam oskarżanie, niszczenie grobów itd. I z tego nie wynika nic dobrego tak w polityce samej, (P4, kod: „lokalna tradycja - nieważna wielokulturowość”).

W Przemyślu nastąpiło rozdzielenie stref wpływów społeczności polskiej (zdecydowanie dominującej) oraz ukraińskiej (mniejszości). Terenem neutralnym jest przeszłość zaboru astro-węgierskiego w postaci Twierdzy Przemyśl. Sferę miejskości i budowania wewnętrznej marki lokalnej na bazie Obchodów Dni Patrona objęła w posiadanie społeczność polska. Wielokulturowość tych terenów w postaci kulturalnej aktywności społeczności ukraińskiej może natomiast realizować się w formie Święta Kupały.

Mogę jeszcze powiedzieć o imprezie, która jest z kolei ukłonem do wielokulturowości, mianowicie Święto Kupały. To jest impreza, którą Związek Ukraińców robi od wielu lat, pokazują obrzęd ten Kupalski, to rzeczywiście tak to bardzo fajnie poprzebierani: dziewczyny, chłopcy. Dziewczyny w wiankach wchodzą do Sanu, te wianki na wodę puszczają, to takie wszystko bardzo ładne, ognisko. To się odbywa zawsze nad Sanem, w okolicach hotelu Gromada, mają takie miejsce ustalone, (P1, kod: „lokalna tradycja - wielokulturowość”). 
I chyba jeszcze dobitniej:

Także, jeśli Ukraińcy coś tam organizują, to dla siebie organizują, tzn. nie na zasadzie, że nie wolno nikomu przyjść, tylko w sensie, że w swoim środowisku. I myślę, że nie zawsze włączają się w to, co u nas się dzieje, ale jest to obserwacja pobieżna. Ja nie prowadziłem analizy, ja nie chciałbym uogólniać, żeby nie powiedzieć jakiejś nieprawdy. Ale na pewno od strony przeżywania tych świąt religijnych bardzo to widać, (P8, kod: „lokalna tradycja - wielokulturowość”).

Wracając do Wincentiady, pozostaje jeszcze pytanie o podmiot odpowiedzialny za organizowanie wydarzenia. W związku z tym, że są to oficjalne Obchody Dni Patrona Miasta, a także biorąc pod uwagę wspomniane wcześniej podziały stref wpływów na przebieg i kształt różnego rodzaju wydarzeń kulturalnych na terenie miasta Przemyśla, domyślić się można, że wskazywano przede wszystkim samorząd miejski wraz z podlegającymi mu instytucjami. Nie bez znaczenia jest także strona odpowiedzialna za religijny i charytatywny aspekt wydarzenia, czyli Klasztor Franciszkanów w Przemyślu i Caritas Archidiecezji Przemyskiej.

Próbując zrekonstruować przyjętą w Przemyślu strategię argumentacyjną dotyczącą Obchodów Dni Patrona Miasta Przemyśla Wincentiada w kontekście lokalnej pamięci społecznej (patrz diagram 2), można stwierdzić, że centralnym punktem jest budowanie tożsamości miejskiej z naciskiem na podkreślanie historii i tradycji miejskich sięgających znacznie dalej w przeszłość niż najbardziej charakterystyczne dla miasta produkty turystyczne. Koncentracja na miejskości nie oznacza jednak sięgania po wielokulturowość, a wymaga wręcz zapominania o tej cesze lokalnej społeczności. Podmiotem reprezentującym społeczność lokalną - w tym przypadku należy to jednak podkreślić - polską jest samorząd miejski oraz instytucje kościoła rzymskokatolickiego. Rezygnacja z pamięci wielokulturowości oznacza dla tych podmiotów przyjęcie roli nie tyle "tłumacza” lokalnej marki, co „prawodawcy” określającego, które elementy złożonej przeszłości wpisują się we współczesną wizję lokalnej marki. Strategia ta może być określona mianem „zapominania o wielokulturowości”. 


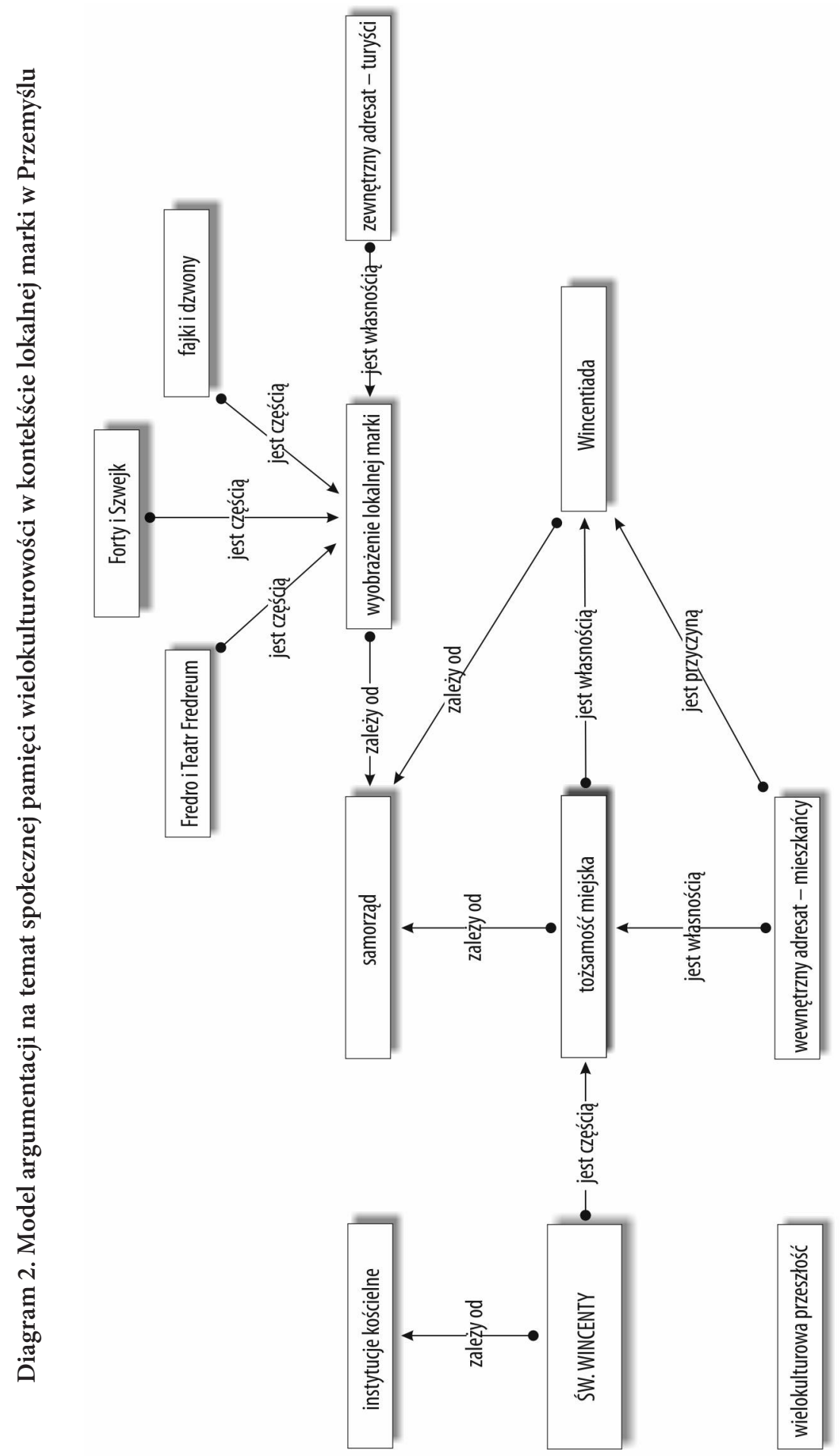




\section{Wnioski}

Podsumowując wyniki przeprowadzonej analizy wtórnej wywiadów pogłębionych, uwidaczniają się dwie różne strategie wykorzystania zasobów w postaci lokalnej pamięci wielokulturowości na potrzeby konstruowania lokalnej marki. W ramach przyjętych założeń teoretycznych są one konsekwencją typu adresata, do którego komunikat marketingowy jest kierowany.

Tabela 1. Strategie wykorzystania elementów pamięci społecznej w konstruowaniu lokalnej marki

\begin{tabular}{|l|l|l|}
\hline \multicolumn{1}{|c|}{ Lokalizacja } & \multicolumn{1}{|c|}{ Sanok } & \multicolumn{1}{c|}{ Przemyśl } \\
\hline Miejskie święto & Jarmark Sanocki & $\begin{array}{l}\text { Dni Patrona Miasta Przemyśla } \\
\text { Wincentiada }\end{array}$ \\
\hline Animatorzy marki & $\begin{array}{l}\text { samorząd miasta wraz } \\
\text { z podlegającymi instytu- } \\
\text { cjami }\end{array}$ & $\begin{array}{l}\text { samorząd miasta wraz z podlegającymi } \\
\text { instytucjami }\end{array}$ \\
\hline $\begin{array}{l}\text { Spójność wyobrażenia } \\
\text { lokalnej marki }\end{array}$ & $\begin{array}{l}\text { duża: powiązanie Muzeum } \\
\text { Budownictwa Ludowego } \\
\text { i Parku Etnograficznego, } \\
\text { Muzeum Historycznego } \\
\text { i wystawy Sztuka Cerkiew- } \\
\text { na XII i XX wieku }\end{array}$ & $\begin{array}{l}\text { niewielka: dla turystów tradycje zaboru } \\
\text { austro-węgierskiego (Twierdza Przemyśl } \\
\text { Wojaka Stowarzyszenie Przyjaciół Dobrego } \\
\text { i fajczarskie oraz Teatr Fredreum; średnio- } \\
\text { wieczny patron miasta dla mieszkańców }\end{array}$ \\
\hline $\begin{array}{l}\text { Adresaci marki w postaci } \\
\text { święta miejskiego }\end{array}$ & turyści & mieszkańcy \\
\hline Cel marki & oryginalność miasta & tradycje miejskości \\
\hline Elementy marki & wielokulturowość & miejskość \\
\hline $\begin{array}{l}\text { Rola pamięci społecznej } \\
\text { w marce }\end{array}$ & $\begin{array}{l}\text { ważna: źródło inspiracji } \\
\text { (wielość odniesień) }\end{array}$ & $\begin{array}{l}\text { ważna: źródło legitymizacji (długie trwa- } \\
\text { nie) }\end{array}$ \\
\hline $\begin{array}{l}\text { Rola wielokulturowości } \\
\text { w pamięci społecznej }\end{array}$ & $\begin{array}{l}\text { ważna: odkrywanie i re- } \\
\text { konstruowanie }\end{array}$ & nieważna: neutralizowanie i zapominanie \\
\hline $\begin{array}{l}\text { Konsekwencja: rola } \\
\text { animatorów marki }\end{array}$ & „tłumacze” & „prawodawcy” \\
\hline
\end{tabular}

Należy podkreślić, że celem artykułu nie jest rozstrzyganie, która z zaobserwowanych i opisanych strategii jest lepsza lub gorsza. Rzecz nie w ocenie jakości, ale w uwypukleniu różnicy pomiędzy dwoma markami miejskimi. W obu przypadkach produkt miejski w postaci miejskiego święta bazuje na elementach lokalnej pamięci społecznej. W obu przypadkach jest jednoznacznie zidentyfikowany animator marki w postaci miejskiego samorządu wraz z podlegającymi mu instytucjami. Jeżeli jednak Jarmark Sanocki skierowany jest przede wszystkim do odbiorcy zewnętrznego, do turysty, najlepiej zagranicznego, to Wincentiada jest zdecydowanie świętem samych przemyślan i w pierwszej kolejności do nich adresowanym. 
Z socjologicznego punktu widzenia niezwykle ciekawy jest proces wykorzystania lokalnych zasobów pamięci społecznej - w tym przypadku na przykładzie pamięci wielokulturowości. Jarmark Sanocki wpisuje się w wizerunek miasta oryginalnego dzięki swojej wielokulturowej przeszłości, odtwarzając tradycje ikonopisarstwa i lokalnego rzemiosła, korelujące z muzealnymi zasobami miasta. Co ciekawe, tradycje te odtwarzane są głównie przez Polaków, mimo że na terenie miasta funkcjonuje aktywna mniejszość ukraińska. Z kolei Wincentiada jest świętem mającym za zadanie jednoczyć mieszkańców miasta, wskazywać historyczne korzenie tożsamości miejskiej, która jest jednoznacznie wiązana z polskością. Pomimo tego, że na terenie miasta funkcjonuje mniejszość ukraińska, a sam Wincenty z Saragossy jest świętym obrządków rzymskokatolickiego, grekokatolickiego i prawosławnego, to wielokulturowość nie jest ważna dla miejskiej tożsamości przemyślan - przynajmniej nie według animatorów marki. Można wręcz odnieść wrażenie, że jest niebezpieczna w tym sensie, że umożliwia wieloznaczne interpretacje tam, gdzie formułowany jest jednoznaczny przekaz na temat polskości miasta.

Ze względu na różnych adresatów, animatorzy marki przyjmują dwie różne strategie sięgania po zasoby lokalnej pamięci społecznej - w Przemyślu jest to strategia „prawodawców”, określających co i w jakim zakresie jest możliwe do wykorzystania ze względu na cel wydarzenia, natomiast w Sanoku jest to chęć „łłumaczenia” charakterystycznych dla miasta wątków. W wywiadach przemyskich wychwycić więc można proces zapominania o wielokulturowości, przynajmniej $\mathrm{w}$ wymiarze zinstytucjonalizowanych świąt miejskich (na przykładzie Wincentiady), z kolei w wywiadach sanockich uwidacznia się proces rekonstruowania wielokulturowości - ponownie jednak raczej w wymiarze zinstytucjonalizowanych świąt miejskich, bowiem wypowiedź przedstawiciela środowisk mniejszości ukraińskiej wskazywała na instrumentalne podejście do tej kwestii ze strony instytucji miejskich.

W zbiorze danych poddanych analizie zabrakło większej liczby wywiadów zrealizowanych $\mathrm{z}$ przedstawicielami mniejszości narodowych na terenie obu miast - nie taki był, co należy raz jeszcze podkreślić, cel pierwotnego badania. Jeden, cytowany zresztą w artykule, wywiad $\mathrm{z}$ przedstawicielem środowisk ukraińskich w Sanoku daje jednak podstawy do sformułowania przypuszczenia, że perspektywa mniejszości byłaby niezwykle ważna dla dokładniejszego odtworzenia strategii wykorzystania społecznej pamięci wielokulturowości w budowaniu miejskiej marki przez polską większość. 


\section{Bibliografia}

Drugi Powszechny Spis Ludności: woj. lwowskie bez miasta Lwowa z dn. 9 XII 1931, 1938, Główny Urząd Statystyczny, Warszawa

Golka M. (2009), Pamięć społeczna i jej implanty, Warszawa.

Hall E. T. (2001), Poza kultura, Warszawa.

Jałowiecki B., Szczepański M.S., Gorzelak G. (2007), Rozwój lokalny i regionalny w perspektywie socjologicznej, Tychy.

Kempny M., Kapciak A., Łodziński S. (1997), Wprowadzenie. Społeczeństwo polskie na progu wielokulturowości, [w:] M. Kempny, A. Kapciak, S. Łodziński (red.), U progu wielokulturowości. Nowe oblicza społeczeństwa polskiego, Warszawa.

Kempny M. (2004), Tradycje lokalne jako podstawa kapitału społecznego. Co tradycja może znaczyć dla społeczności lokalnej w dobie globalizacji? [w:] J. Kurczewska (red.), Oblicza lokalności. Tradycja i współczesność, Warszawa.

Kempny M. (2005), Granice wspólnot i „pograniczne” tożsamości, [w:] J. Kurczewska, H. Bojar (red.), Granice na pograniczach. Z badań społeczności lokalnych wschodniego pogranicza Polski, Warszawa.

Kurczewska J. (2009), Zakończenie, czyli stare i nowe argumenty przeciw „wyciskaniu brukselki”, [w:] J. Kurczewska, H. Bojar (red.), Wyciskanie brukselki? O europeizacji społeczności lokalnych na pograniczach, Warszawa.

Kwiatkowski P. T. (2009), Czy lata III Rzeczypospolitej były „czasem pamięci”?, [w:] A. Szpociński (red.), Pamięć zbiorowa jako czynnik integracji i źródło konfliktów, Warszawa.

Michałowski L. (2003), Turystyka i sposoby promocji miast, „Studia Regionalne i Lokalne” nr 4(14), s. 91-110.

Narodowy Spis Powszechny z dn. 20 V 2002, Warszawa 2002, Główny Urząd Statystyczny: http://stat.gov.pl/spisy-powszechne/narodowe-spisy-powszechne/narodowy-spispowszechny-2002, [15.04.2018].

Perzyńska A. (2013), Marka w marketingu terytorialnym, „Prace Naukowe Uniwersytetu Ekonomicznego we Wrocławiu. Gospodarka przestrzenna: uwarunkowania ekonomiczne, prawne i samorządowe" nr 320, s. 120-127

Raszkowski A. (2013), Emocjonalne wymiary marki miasta, „Prace Naukowe Uniwersytetu Ekonomicznego we Wrocławiu. Gospodarka lokalna w teorii i praktyce”, nr 284, s. 81-89.

Szacka B. (2006), Czas przeszły, pamięć, mit, Warszawa.

Żabińska T. (red.) (2012), Turystyka na obszarach miejskich. Uwarunkowania rozwoju. Narzędzia promocji, „Studia Ekonomiczne UE w Katowicach, Zeszyty Naukowe Wydziałowe", nr 119.

Żabińska T. (red.), (2013), Turystyka miejska. Prawidłowości i determinanty rozwoju, „Studia Ekonomiczne UE w Katowicach, Zeszyty Naukowe Wydziałowe” nr 147.

Główny Urząd Statystyczny, 2016, Turystyka w 2015 roku. Informacje i Opracowania Statystyczne, Warszawa

Ministerstwo Sportu i Turystyki, 2015, Program rozwoju turystyki do 2020 roku. Projekt, Warszawa (https://bip.msit.gov.pl/bip/projekty-aktow-prawnyc/zakonczony-proceslegi/inne/1599,Program-Rozwoju-Turystyki-do-2020-roku.html). 


\section{SUMMARY}

\section{The Elements of Social Memory in Constructing the Local Brand. Local Multicultural Past as (no)Product of Tourist - Strategies in Przemyśl and Sanok}

Present popularity of local tourist products may motivate local municipal environments to reach for specificity based on locality. Local specificity can result from localization on borderland and its multiculturalism. Furthermore, mechanisms of local memory may lead to conscious resignation from these elements of the past that recall multiculturalism of the place.

The presented analysis are of secondary character - the in-depth interviews with local brand animators have been focused on issues related to organization of town festival but not on social memory. However, both festivals refer to the past, so it is possible to verify whether local multicultural past is or is not tourist product in Przemyśl or Sanok. The main factor seems to be local memory of local brand animators.

KEYWORDS: municipal brand, social memory, tourist product, multiculturalism 